\title{
Economic Growth from a Kaldorian Perspective: Theory, Evidence and Agenda*
}

\author{
João P. Romero ${ }^{\dagger}$
}

\begin{abstract}
This paper presents a literature review of the Kaldorian literature, which identifies three important gaps, or areas for future research. Firstly, the determinants of the magnitude of the key parameters of Kaldor-Verdoorn's Law (the Verdoorn coefficient) and of Thirlwall's Law (the income elasticities) have not been fully understood. Secondly, the fact that cumulative causation works through price competitiveness in the Kaldor-Dixon-Thirlwall model represents an important limitation of the model, which has not yet been solved. Thirdly, sectoral differences have not been fully explored in Kaldorian theory. The review indicates that, in the first two research areas, exploring the effects of additional variables could help clarify what determines the magnitudes of the parameters, as have been sought by the works that combine Kaldorian and Schumpeterian insights, indicating also new channels through which cumulative causation could work. Finally, the last issue requires more attention to similarities and differences between manufacturing sectors, as well as exploring more carefully how sectoral dynamics work.
\end{abstract}

Keywords: Kaldorian growth models; Economic growth; Thirlwall's law; Verdoorn's law.

JEL Classification: 014; 041; E12.

\footnotetext{
* The author would like to thank Professor John McCombie for his helpful comments. The usual disclaimer applies. Financial support from the Coordination for the Improvement of Higher Education Personnel (CAPES-Brazil), process number 0257-11-7, is gratefully acknowledged.

${ }^{\dagger}$ Department of Economics and Center for Regional Development and Planning (CEDEPLAR), Universidade Federal de M inas Gerais (UFM G)
} 


\section{Introduction}

Nicholas Kaldor's works cover a number of different subjects in economic theory, such as cumulative causation, regional policy, taxation, income distribution, economic growth, balance-of-payments, and technical progress. Nonetheless, three of Kaldor's ideas were particular influential (M cCombie, 2002: 64-5).

The most influential of Kaldor's contributions to economic theory relates to the importance of increasing returns to scale for productivity growth. Kaldor (1966) strongly emphasized that the main source of productivity growth is technical progress. According to him, technical progress is determined by demand growth, which fosters increases in division of labour. Hence, following Keynes' (1936) demand-led approach to economic growth, Kaldor's ideas contribute to understanding how demand growth influences technical progress.

Kaldor's second influential contribution to growth theory relates to the importance of exports for long-term growth. Keynesian economics emphasizes the importance of investment for economic growth. Kaldor, however, stressed that exports is the most important component of autonomous demand in open economies, given that long-term growth is constrained by balance-of-payments disequilibria, provided that growing debt cannot be indefinitely financed. Thus, again Kaldor extrapolates the Keynesian demand-led approach by stressing the importance of external demand for long-term growth.

Finally, Kaldor's third influential contribution to growth theory relates to the importance of cumulative causation in the process of economic growth. In contrast with the neoclassical growth theory, which focuses on the role of mechanisms that lead economies to converge, Kaldor (like Myrdal, 1957) emphasized the importance of cumulative mechanisms that slow down convergence or make economies diverge. This argument is closely linked to his emphasis on increasing returns, since the interplay between demand growth and productivity growth forms a cumulative circuit of growth.

The objective of this paper is to discuss the models derived from the three main Kaldorian insights, identifying the main shortcomings of the existing literature, while presenting the most recent contributions and pointing out promising venues for future development. The general objective of this paper, therefore, is to present a broad and up to date revision of the Kaldorian literature, that could serve as guide for future research in the field. More specifically, the objectives are threefold: (i) emphasize the relevance of testing the determinants of the magnitude of returns to scale; (ii) highlight the importance of testing what determines the magnitude of income elasticities of trade; and (iii) discuss the shortcomings and possibilities of expansion of the canonical Kaldor-Dixon-Thirlwall model of cumulative growth.

The paper is organized as follows. Section 2 analyses the Kaldorian literature that studies the importance of increasing returns and technical progress for productivity growth. Section 3 discusses the literature that explores the determinants of the long-term growth under the balance-of-payments equilibrium constraint. Section 4 discusses the canonical model of cumulative causation that sought to bring together Kaldor's ideas discussed in sections 2 and 3 . Section 5 concludes the paper. 


\section{Increasing returns to scale and technical progress}

\subsection{Kaldor-Verdoorn's Law}

Kaldor's ideas about the role of demand growth in generating technical progress, productivity growth, and increasing returns are summarized in Kaldor-Verdoorn's Law. ${ }^{1}$ As McCombie (2002) showed, this law can be expressed in a variety of forms.

Verdoorn (1949) used the simple relationship between output growth and productivity growth to assess the importance of demand growth for technical progress:

$\hat{Q}=\rho+\lambda \hat{Y}$

where $Q$ and $Y$ are manufacturing productivity and output, respectively, and the circumflex over the variables indicates growth rates. Moreover, $\rho$ is autonomous productivity growth and $\lambda$ is the elasticity of productivity with respect to demand growth, or the Verdoorn coefficient.

Kaldor (1966), in turn, proposed an alternative but equivalent formulation of the law, by substituting the identity $\hat{Q} \equiv \hat{Y}-\hat{L}$ into equation (1) to find:

$\hat{L}=-\rho+(1-\lambda) \hat{Y}$

According to Kaldor (1966), this specification is preferable to Verdoorn's (1949), given that it avoids spurious correlation resulting from the fact that output growth is used to calculate productivity growth. As Kaldor (1966) stressed, however, as a Verdoorn coefficient positive and significantly different from zero in equation (1) indicates the existence of increasing returns to scale (i.e. $\lambda>0$ ), an elasticity of employment growth with respect to demand growth statistically different from unity in equation (2) indicates the existence of increasing returns to scale as well (i.e. $0<(1-\lambda) \neq 1$ ). This implies that the law represents a technical relationship derived from Kaldor's (1957) technical progress function (see Dixon and Thirlwall, 1975).

Several years after Kaldor's seminal work on Kaldor-Verdoorn's Law, however, McCombie (2002) observed that the law could be derived from a production function framework. ${ }^{2}$ Following Angeriz et al. (2009), the starting point of the model is a production function like:

$Y=A K^{\alpha} L^{\beta}$

where $Y$ is total value added, $K$ is the stock of capital, $L$ is labour, and $A$ is the level of technology. Moreover, $\alpha$ and $\beta$ are respectively the output elasticities of capital and labour, so that $(\alpha+\beta)=\gamma\left[\alpha^{\prime}+\left(1-\alpha^{\prime}\right)\right]$, where $\gamma$ is a measure of the degree of static returns to scale and $\alpha^{\prime}$ is the share of capital in total value added.

Assuming the existence of external increasing returns to scale, the growth of weighted factor inputs determines the rate of technical progress $\left(g_{A}\right)$ :

\footnotetext{
${ }^{1}$ See McCombie (2002) for detailed discussions of Kaldor-Verdoorn's Law in its different specifications and of types of returns to scale.

${ }^{2}$ M cCombie and Spreafico (2016) have shown that the Kaldor-Verdoorn Law represents a meaningful behavioural relationship. Hence, the law does not result from the value added accounting identity (see Felipe et al., 2008).
} 


$$
g_{A} \equiv \dot{A} / A=\phi+\eta T \hat{F} I
$$

where $\varphi$ is the exogenous technical progress, $\eta$ is the elasticity of induced technological progress, and $T \hat{F} I \equiv \alpha^{\prime} \hat{K}+\left(1-\alpha^{\prime}\right) \hat{L}$ is the growth rate of total factor inputs (TFI). In contrast with the endogenous growth models developed by Romer (1990), Grossman and Helpman (1991), Aghion and Howitt (1992), inter alia, in the Kaldorian approach it is demand growth that determines technological progress, given that the growth of inputs is driven by the growth of demand in a Keynesian perspective, i.e. $T \hat{F} I=f(\hat{Y})$. Consequently, this means that the rate of induced technical change is ultimately a function of the growth of demand.

Hence, substituting equation (4) into the production function (3), taking logarithms, differentiating with respect to time, and rearranging gives the dynamic demand-side KaldorVerdoorn's Law:

$$
\hat{T F P}=\left(\frac{\phi}{v}\right)+\left(1-\frac{1}{v}\right) \hat{Y}
$$

where $v=\gamma+\eta$. The growth rate of total factor productivity (TFP) is defined as $T \hat{F} P \equiv \hat{Y}-T \hat{F} I$.

Equation (5), therefore, indicates that productivity growth is determined by the growth rate of value added, which is driven by the growth of demand in Kaldor's approach. Thus, if $\gamma>1$ (i.e. $\beta>1-\alpha$ ) there are static increasing returns to scale, while if $\eta>0$ there are dynamic increasing returns to scale, i.e. induced technical progress. The parameter $v$, therefore, indicates the degree of encompassing returns to scale, so that if $v>1$ the second term between parentheses in equation (5) is above zero, which indicates the existence of increasing returns to scale. Furthermore, the TFP specification of Kaldor-Verdoorn's Law given by equation (5) is preferable to Verdoorn (1949) and Kaldor's (1966) versions of the law due to the fact it takes capital accumulation into account.

\subsection{Empirical evidence}

After the seminal empirical evidence found by Verdoorn (1949) and Kaldor (1966) suggesting the existence of increasing returns in manufacturing, Kaldor-Verdoorn's Law was tested in a large number of works both for developed and developing countries (e.g. Hansen and Zhang, 1996; Harris and Liu, 1999; Oliveira et al., 2006), across different sectors (e.g. McCombie and De Ridder, 1983; León-Ledesma, 2000; Angeriz et al., 2009), and using different econometric techniques (e.g. McCombie and De Ridder, 1984; León-Ledesma, 2000; Angeriz et al., 2008; Britto and McCombie, 2015). In addition, a number of critiques directed to the law have been dismissed over time (see McCombie, 2002; M cCombie and Roberts, 2007).

Table 1 summarizes the results of some of the works that have tested KaldorVerdoorn's Law. This table shows that almost 50 years after Kaldor's 1966 inaugural lecture, there is still some controversy about the validity of the law. While earlier studies found that the law holds for its dynamic demand-side (Kaldor, 1966) and supply-side (Rowthorn, 1975) versions, but not for the static specifications (e.g. McCombie and De Ridder, 1983, 1984; LeónLedesma, 1999, 2000), recent studies have found that the law only holds for the demand-side version in its dynamic and static forms, but not for the supply-side specifications (Angeriz et al., 2008; 2009). Thus, it seems that further work is still necessary to reconcile all its specification. 
Table 1: Estimates of Kaldor-Verdoorn's Law

\begin{tabular}{|c|c|c|c|c|c|c|}
\hline \multirow[b]{2}{*}{ Study } & \multirow[b]{2}{*}{$\begin{array}{l}\text { Spatial } \\
\text { Coverage }\end{array}$} & \multirow[b]{2}{*}{ Method } & \multicolumn{2}{|c|}{ Dynamic law } & \multicolumn{2}{|c|}{ Static law } \\
\hline & & & $\begin{array}{l}\text { Demand- } \\
\text { side }\end{array}$ & $\begin{array}{l}\text { Supply- } \\
\text { side }\end{array}$ & $\begin{array}{l}\text { Demand- } \\
\text { side }\end{array}$ & $\begin{array}{l}\text { Supply- } \\
\text { side }\end{array}$ \\
\hline Kaldor (1966) & 12 OECD & OLS & IRS & - & - & - \\
\hline McCombie (1982) & $12 \mathrm{OECD}$ & OLS & IRS & - & CRS & - \\
\hline McCombie and Rider (1983) & US & VECM & IRS & IRS & - & - \\
\hline McCombie and Rider (1984) & US regions & $\begin{array}{l}\text { OLS, IV with } \\
\text { regional } \\
\text { dummies }\end{array}$ & IRS & IRS & CRS & CRS \\
\hline Hansen and Zang (1996) & China regions & OLS & IRS & - & - & - \\
\hline Bernat (1996) & US regions & $\begin{array}{c}\text { OLS, SEM, } \\
\text { SAR }\end{array}$ & IRS & - & - & - \\
\hline Fingleton and McCombie (1998) & EU regions & OLS, SAR & IRS & - & CRS & - \\
\hline Harris and Liu (1999) & 60 countries & VECM & IRS & - & - & - \\
\hline León-Ledesma (1999) & Spain regions & OLS, FE, RE & IRS & IRS & - & - \\
\hline León-Ledesma (2000) & Spain regions & OLS, FE, RE & IRS & IRS & IRS & CRS \\
\hline León-Ledesma (2002) & 17 OECD & 3SLS, 2SLS & IRS & - & - & - \\
\hline Oliveira et al. (2006) & Brazil & VECM & IRS & - & - & - \\
\hline Angeriz et al. (2008) & EU regions & $\begin{array}{c}\text { OLS, SAR, } \\
\text { SEM, SHM, } \\
\text { FGS2SLS, FE }\end{array}$ & IRS & CRS & IRS & CRS \\
\hline Angeriz et al. (2009) & EU regions & SHM, IV, FE & IRS & CRS & IRS & - \\
\hline
\end{tabular}

Note: IRS = Increasing Returns to Scale; $\mathrm{CRS}=$ Constant Returns to Scale.

Source: Author's elaboration.

Yet, in spite of the large number of works that have investigated Kaldor-Verdoorn's Law, not much is known about the specific factors that determine differences in the degrees of returns to scale across countries, sectors or through time. Pieper (2003) has provided evidence that the law is non-linear, suggesting that increasing returns to scale reduce at higher rates of output growth for agriculture and increase at higher rates of output growth for manufacturing. In contrast, Alexiadis and Tsagidis (2010) found evidence that output growth exerts a negative impact on subsequent productivity growth, i.e. reduces the future degree of returns to scale, even when controlling for technological diffusion. In addition, in a regional analysis, using firmlevel data from Brazil, Britto and McCombie (2015) provided evidence that that higher urbanization economies (proxied by service density) lead to higher returns to scale even when controlling for technology gap and human capital. Most recently, Romero and McCombie (2016a) have found evidence that high-tech industries present higher increasing returns than low-tech industries, while the magnitude of the returns to scale has increased in the high-tech industries from the period 1976-1991 to the period 1992-2006. In addition, in a subsequent study, Romero and Britto (2016) have found evidence that higher research intensity (measured as patents per hours worked or R\&D per output) research intensity increases the response of technical progress to output growth, influencing the magnitude of returns to scale. The Verdoorn coefficient is a measure of encompassing returns to scale, including induced technical progress, internal economies of scale and the division of labour broadly defined. Thus, a higher value of the coefficient reflects a greater effect of the growth of output in raising (inducing) the growth of productivity. Consequently, assuming that research intensity makes the industry's productivity growth more responsive to demand growth, the Verdoorn coefficient becomes positively related to the degree of research intensity. Formally, this means that the Verdoorn coefficient $(\delta=(1-1 / v)$ in equation (5)) becomes partially endogenous, given by: $\delta=\rho+\varepsilon T$.

Hence, productivity growth becomes dependent not only on output growth, but also on the interaction between output growth and research intensity. This means that countries with higher levels of research intensity benefit from higher increasing returns when output grows. In this model, therefore, research intensity is assumed to be an exogenous variable. 
Schmookler (1966) has found evidence of a strong relationship between investment in capital goods user industries and patent applications by capital goods producing industries, which suggests that patenting is a function of effective demand ("demand pull" hypothesis). However, this finding is not free from problems. For example, in a re-examination of Schmookler's findings using data from the Dutch economy, Kleinknecth and Verspagen (1990: 394) found evidence of a mutual dependence between demand and innovations, which suggests that not only demand may favour innovation, but also innovation may induce extra demand. Moreover, in León-Ledemsma's (2002) tests, demand has no significant contemporaneous impact on research intensity. Consequently, although the relationship between demand and research intensity deserves further investigation, it is reasonable to consider that research intensity has an exogenous impact on the magnitude of returns to scale.

Most importantly, the form of endogenising the Verdoorn Coefficient proposed by Romero and Britto (2016) creates the possibility of testing the impact of new variables on the determinants of returns to scale, opening an promising area for subsequent research.

\section{Export-led growth and balance-of-payments constrained growth models}

\subsection{Thirlwall's Law}

In a Keynesian perspective, demand growth drives economic growth. Consequently, differences in output growth rates between countries reflect differences in the rates of growth of demand for each country's production. As McCombie and Thirlwall (1994, p. 88) stressed, however, in Kaldor's (1970) view, "it is not investment, as Keynes argues, that is the key element of exogenous demand, but, in an open economy, the growth of demand for a country's exports".

The role of exports in the Kaldorian theory of economic growth is twofold. Firstly, export growth, as a component of aggregate demand, has a direct impact on output growth. Secondly, export growth has also an indirect impact on output growth, given that exports generate the foreign currency that allows other components of demand to grow, provided that increasing consumption and investment often require higher imports, and a growing foreign debt cannot be financed indefinitely. ${ }^{3}$ This theory implies that, in the long-term, the requirement of balance-of-payments equilibrium is the main constraint determining differences in demand growth across countries, given that aggregate demand must adjust to solve balance-of-payments disequilibria.

Kaldor's (1970) ideas on the importance of exports for long-term growth were extrapolated and formalised by Thirlwall (1979), who put together a balance-of-payments constrained growth model composed of three equations: an export function, an import function, and a balance-of-payments equilibrium condition, respectively:

$$
\begin{aligned}
& X=a\left(\frac{P}{P_{f} E}\right)^{\eta} Z^{\varepsilon} \\
& M=b\left(\frac{P_{f} E}{P}\right)^{\psi} Y^{\pi}
\end{aligned}
$$

\footnotetext{
${ }^{3}$ See McCombie (1985) for a formal demonstration that Harrod's (1933) foreign trade multiplier is a component of Hick's (1950) super-multiplier.
} 
where $E$ is the exchange rate, $M$ is imports, $X$ is exports, and $P$ and $P_{f}$ are the domestic and the foreign price levels, respectively. Moreover, $Z$ and $Y$ are the foreign and domestic income levels, $\eta<0$ and $\psi<0$ are the price elasticities of demand for exports and imports, $\varepsilon>0$ and $\pi>0$ are the income-elasticities of demand for exports and imports, respectively. Finally, a and $b$ are constants. time yields:

Hence, taking logarithms and differentiating each of these equations with respect to

$$
\begin{aligned}
& \hat{X}=\eta\left(\hat{P}-\hat{P}_{f}-\hat{E}\right)+\varepsilon \hat{Z} \\
& \hat{M}=\psi\left(\hat{P}_{f}-\hat{P}+\hat{E}\right)+\pi \hat{Y} \\
& \hat{P}+\hat{X}=\hat{P}_{f}+\hat{E}+\hat{M}
\end{aligned}
$$

Thus, substituting equations (9) and (10) into equation (11) yields the long-term rate of growth of domestic income compatible with balance-of-payments equilibrium:

$$
\hat{Y}_{B O P 1}=\frac{(1+\eta+\psi)\left(\hat{P}-\hat{P}_{f}-\hat{E}\right)+\varepsilon \hat{Z}}{\pi}
$$

Equation (12) has several implications. First, domestic inflation higher than foreign inflation, ceteris paribus, decreases the balance-of-payments equilibrium growth (provided the Marshall-Lerner condition $|\psi+\eta|>1$ holds). Second, exchange-rate depreciations $(\hat{E}>0)$, ceteris paribus, raise the balance-of-payments equilibrium growth rate (provided $|\psi+\eta|>1$ ). Third, a higher rate of growth of world income $(\hat{Z})$, ceteris paribus, raises the balance-ofpayments equilibrium growth rate. And fourth, the higher the income-elasticity of demand for exports $(\varepsilon)$ is, and the lower the income-elasticity of demand for imports $(\pi)$ is, ceteris paribus, the higher is the balance-of-payments equilibrium growth rate.

Nonetheless, if relative prices are assumed to be constant in the long run, i.e. $\hat{P}-\hat{P}_{f}-\hat{E}=0$, then equation (12) is reduced to Thirlwall's Law: ${ }^{4}$

$$
\hat{Y}_{B O P 1}=\frac{\varepsilon \hat{Z}}{\pi}
$$

or

$$
\hat{Y}_{B O P 1}=\frac{\hat{X}}{\pi}
$$

Equation (13) is Thirlwall's Law in its "strong form", while equation (14) is the "weak form" of the law. These equations highlight the importance of the income elasticities for longterm growth. ${ }^{5}$

\footnotetext{
${ }^{4}$ This equation is equivalent to Harrod's (1933) foreign trade multiplier in its dynamic version (see McCombie, 1985).

${ }^{5} \mathrm{~A}$ number of works have expanded the original balance-of-payments constrained growth model presented in this section to incorporate the effects of capital flows on growth, debt accumulation and interest payments into the model (e.g. Thirlwall and Hussain, 1982; McCombie and Thirlwall, 1997; Moreno-Brid, 2003; Barbosa-Filho, 2001). Still, it is reasonable to assume that such factors are not relevant for long-term growth.
} 


\subsection{The Multi-Sectoral Thirlwall's Law}

Although it has been always clear that the overall price and income elasticities of demand are weighted averages of sectoral income elasticities, Araújo and Lima (2007) were the first to develop a formal model that takes sectoral differences in the elasticities into account. Their model, however, is derived from a Pasinetian framework. Still, it is simple to obtain similar results using the standard balance-of-payments constrained growth model.

Assuming an economy composed of i sectors, each one subject to different price and income elasticities of demand, the overall export and import equations (9) and (10) become:

$$
\begin{aligned}
& \hat{X}=\sum_{i=1}^{k}\left[\varphi_{i} \eta_{i}\left(\hat{P}_{i}-\hat{P}_{f i}-\hat{E}\right)+\varphi_{i} \varepsilon_{i} \hat{Z}\right] \\
& \hat{M}=\sum_{i=1}^{k}\left[\theta_{i} \psi_{i}\left(\hat{P}_{f i}-\hat{P}_{i}+\hat{E}\right)+\theta_{i} \pi_{i} \hat{Y}\right]
\end{aligned}
$$

where $\phi_{i}$ and $\theta_{i}$ are each sector's share in total exports and imports, respectively, with $\sum_{i=1}^{k} \varphi_{i}=1$ and $\sum_{i=1}^{k} \theta_{i}=1$. From | equations (15) and (16), since $\varepsilon=\sum_{i=1}^{k} \varphi_{i} \varepsilon_{i}, \quad \pi=\sum_{i=1}^{k} \theta_{i} \pi_{i}$, $\eta=\sum_{i=1}^{k} \phi_{i} \eta_{i}$, and $\psi=\sum_{i=1}^{k} \theta_{i} \psi_{i}$, the overall elasticities shift according to changes in the sectoral composition of the economy.

Hence, substituting equations (15) and (16) into the balance-of-payments equilibrium condition given by equation (8) yields:

$$
\hat{Y}_{\text {MSBOP }}=\frac{\left(\sum_{i=1}^{k}\left[\left(1+\sigma_{i} \eta_{i}+\omega_{i} \psi_{i}\right)\left(\hat{P}_{i}-\hat{P}_{f i}-\hat{E}\right)+\varphi_{i} \varepsilon_{i} \hat{Z}\right]\right)}{\left(\sum_{i=1}^{k} \theta_{i} \pi_{i}\right)}
$$

Equation (17) is the Multi-Sectoral version of equation (12). Thus, assuming that relative prices are constant in the long-term, equation (17) becomes:

$$
\hat{Y}_{M S B O P}=\frac{\left(\sum_{i=1}^{k} \varphi_{i} \varepsilon_{i}\right) \hat{Z}}{\left(\sum_{i=1}^{k} \theta_{i} \pi_{i}\right)}
$$

Equation (18) is equivalent to what Araújo and Lima (2007) called the Multi-Sectoral Thirlwall's Law (MSTL). This equation indicates that shifts in the productive structure (i.e. sectoral shares) affect the long-term growth rate compatible with balance-of-payments equilibrium. Hence, a country's growth rate can increase even if the rest of the world continues to grow at the same pace (i.e. a constant $\hat{Z}$ ), as long as the composition of exports and imports is favourably altered. In sum, equation (18) stresses that the equilibrium growth rate depends on the sectoral structure of the economy. In particular, structural changes toward sectors with higher income elasticities of demand for exports will raise the economy's long-term growth rate, ceteris paribus.

\subsection{Empirical evidence}


Thirlwall's Law has been tested for a large number of countries using a variety of estimation techniques (e.g. Bairam, 1988; Bairam and Dempster, 1991; Atesoglu, 1993a; 1993b; Andersen, 1993; Alonso and Garcimartín, 1998; Perraton, 2003; Jayme Jr., 2003; Britto and McCombie, 2009; Garcimartín et al., 2010). In addition, a number of works have tested the extended balance-of-payments constrained growth model that take into account capital flows, debt accumulation and debt payments, and in most cases the original Thirlwall's Law is found to hold (e.g. Thirlwall and Hussain, 1982; Barbosa-Filho, 2001; M oreno-Brid, 2003; Britto and McCombie, 2009). As happens with Kaldor-Verdoorn's Law, several critiques directed to Thirlwall's Law have been dismissed over time (see M cCombie, 2011).

Table 2 summarizes the results found by some of the works that have tested Thirlwall's Law. This table shows that the empirical works that assess Thirlwall's Law strongly suggest its validity for a diverse sample of countries, over different periods, using different estimation techniques, and adopting different specifications. This implies that only by increasing a country's income-elasticity of exports and/or by decreasing its income-elasticity of imports a country can consistently overcome the balance-of-payments constraint and raise its long-term growth rate.

In spite of the large literature on Thirlwwall's Law, however, as happens with the literature on increasing returns to scale, not much is known about the determinants of the income elasticities of demand. Most recently, following the contribution of Araújo and Lima (2007), who elaborated a multi-sectoral version of Thirlwall's Law, some works have been exploring the connection between the sectoral composition of trade and the magnitudes of aggregate income elasticities. Gouvea and Lima (2010) and Romero et al. (2011) have estimated export and import demand functions for different technological sectors, and found that goods with high technological content present higher income elasticities, which implies higher shares of these goods in trade increase the aggregate income elasticity of exports. Similarly, Tharnpanich and M cCombie (2013) have estimated export and import functions for manufacturing and primary sectors, and found that manufacturing goods face higher income elasticities. Gouvea and Lima (2013) have also estimated export and import functions adopting a sectoral classification that follows categories of use, and found that capital goods have higher income elasticities than consumption and intermediary goods. Finally, Romero and McCombie (2016b) reported estimates of import and export functions for five technological sectors in 14 developed European countries. The results indicated once again that the income elasticities of exports and imports are higher for medium- and high-tech manufactures. The paper provided also an important contribution in terms of the method of estimation of export and import functions. Comparing the results found using Vector Error Correction Models (adopting aggregate price indexes as deflators and measures of relative prices) with the results found using cross-product panels (adopting product-level quality-adjusted price indexes as deflators and measures of relative prices) revealed that the latter estimation strategy generates more reliable and less volatile results. Moreover, the investigation indicated that the Multi-Sectoral Thirlwall's Law holds for the countries investigated. However, moving exports (imports) from (to) low-tech sectors to (from) high-tech sectors seems to be a necessary but not sufficient condition to increase long-term growth, given that countries with similar sectoral compositions of trade present different equilibrium growth rates. 
Table 2: Estimates of Thirlwall's Law

\begin{tabular}{|c|c|c|c|c|c|c|}
\hline Studies & $\begin{array}{c}\text { Spatial } \\
\text { Coverage }\end{array}$ & $\begin{array}{l}\text { Estimation } \\
\text { Method }\end{array}$ & Specification & Period & Relative Price Measure & Test \\
\hline $\begin{array}{l}\text { Houthakker and } \\
\text { Magee (1969) }\end{array}$ & 40 Countries & OLS & Basic & $1951-66$ & $\begin{array}{l}\text { Import price deflator to } \\
\text { the country's wholesale } \\
\text { price index; export price } \\
\text { deflator to the average } \\
\text { export price deflator of } \\
26 \text { countries. }\end{array}$ & - \\
\hline Thirlwall (1979) & $\begin{array}{l}14 \text { Developed } \\
\text { Countries }\end{array}$ & - & - & $1951-66$ & - & Cor.* \\
\hline $\begin{array}{l}\text { Thirlwall and } \\
\text { Hussain (1982) }\end{array}$ & $\begin{array}{c}16 \\
\text { Developing } \\
\text { Countries }\end{array}$ & - & - & $1951-66$ & - & Cor.* \\
\hline Bairam (1988) & $\begin{array}{l}19 \text { Developed } \\
\text { Countries }\end{array}$ & 2SLS & Basic & $1970-85$ & $\begin{array}{l}\text { Unit Value Price Indexes } \\
\text { in US dollars }\end{array}$ & Reg.* \\
\hline $\begin{array}{l}\text { Bairam and } \\
\text { Dempster (1991) }\end{array}$ & $\begin{array}{l}11 \text { Asian } \\
\text { Countries }\end{array}$ & OLS, VECM & Basic & $1970-96$ & $\begin{array}{l}\text { Unit Value Price Indexes } \\
\text { in US dollars }\end{array}$ & $\begin{array}{l}\text { Reg.*; } \\
\text { Elast.* }\end{array}$ \\
\hline Atesoglu (1993a) & US & OLS, 2SLS & Basic & $1955-90$ & $\begin{array}{l}\text { GNP deflator to the } \\
\text { implicit import deflator }\end{array}$ & Reg.* \\
\hline Atesoglu (1993b) & Canada & OLS & $\begin{array}{l}\text { Including } \\
\text { capital flows }\end{array}$ & $1961-91$ & $\begin{array}{l}\text { GNP deflator to the } \\
\text { implicit import deflator }\end{array}$ & - \\
\hline Andersen (1993) & $\begin{array}{l}16 \text { Developed } \\
\text { Countries }\end{array}$ & VECM & Basic & $1960-90$ & $\begin{array}{c}\text { Domestic demand } \\
\text { deflator to import price } \\
\text { deflator; and relative unit } \\
\text { labour costs }\end{array}$ & Reg.* \\
\hline Heike (1997) & US & OLS & Basic & $1950-90$ & Real Exchange Rate. & - \\
\hline McCombie (1997) & $\begin{array}{l}\text { US, UK, } \\
\text { Japan }\end{array}$ & VECM & Basic & $1952-93$ & $\begin{array}{l}\text { Import price deflator to } \\
\text { export price deflator. }\end{array}$ & Elast.** \\
\hline $\begin{array}{l}\text { Alonso and } \\
\text { Garcimartín } \\
\text { (1998) }\end{array}$ & Spain & VECM & $\begin{array}{l}\text { Includes } \\
\text { technology } \\
\text { index }\end{array}$ & $1965-94$ & $\begin{array}{l}\text { Import price deflator to } \\
\text { export price deflator. }\end{array}$ & $\begin{array}{l}\text { Reg.****; } \\
\text { Coint.****; } \\
\text { Adj.****; }\end{array}$ \\
\hline $\begin{array}{l}\text { Ansari et al. } \\
(2000)\end{array}$ & $\begin{array}{l}4 \text { Asian } \\
\text { Countries }\end{array}$ & OLS, VECM & Basic & $1970-96$ & $\begin{array}{l}\text { Difference between the } \\
\text { growth rate of foreign } \\
\text { and domestic prices. }\end{array}$ & $\mathrm{t}$-test $* * *$ \\
\hline Jayme Jr. (2003) & Brazil & VECM & Basic & $1955-1998$ & - & Cor.* \\
\hline Perraton (2003) & $\begin{array}{l}27 \\
\text { Developing } \\
\text { Countries }\end{array}$ & VECM & Basic & $1960-93$ & $\begin{array}{l}\text { Unit Value Price Indexes } \\
\text { in US dollars. }\end{array}$ & $\begin{array}{l}\text { Elast.***; } \\
\text { Reg.**** }\end{array}$ \\
\hline $\begin{array}{l}\text { Moreno-Brid } \\
(2003)\end{array}$ & Mexico & VECM & $\begin{array}{l}\text { Includes tariff } \\
\text { protection }\end{array}$ & $1967-99$ & $\begin{array}{l}\text { Import price deflator to } \\
\text { export price deflator. }\end{array}$ & Elast. $* * * *$ \\
\hline $\begin{array}{l}\text { Britto and } \\
\text { McCombie (2009) }\end{array}$ & Brazil & VECM & Basic & $1951-2006$ & Real Exchange Rate. & $\begin{array}{l}\text { Elast. } * * * * ; \\
\text { Coint. } * * * *\end{array}$ \\
\hline $\begin{array}{l}\text { Garcimartín et al. } \\
(2010)\end{array}$ & $\begin{array}{l}\text { Portugal and } \\
\text { Spain }\end{array}$ & ML & $\begin{array}{l}\text { Modified } \\
\text { version }\end{array}$ & $1975-2007$ & $\begin{array}{l}\text { Difference between the } \\
\text { growth rates of foreign } \\
\text { and domestic prices, and } \\
\text { the exchange rate. }\end{array}$ & Adj.**** \\
\hline $\begin{array}{l}\text { Gouvea and Lima } \\
(2010)\end{array}$ & $\begin{array}{c}4 \text { Latin } \\
\text { American and } \\
4 \text { Asian } \\
\text { Countries }\end{array}$ & VECM & $\begin{array}{l}\text { Multi- } \\
\text { Sectoral } \\
\text { Version }\end{array}$ & $1962-2006$ & Real Exchange Rate. & t-test* \\
\hline $\begin{array}{l}\text { Romero et al. } \\
(2011)\end{array}$ & Brazil & VECM & $\begin{array}{l}\text { Multi- } \\
\text { Sectoral } \\
\text { Version }\end{array}$ & $1962-2006$ & Real Exchange Rate. & - \\
\hline $\begin{array}{l}\text { Tharnpanich and } \\
\text { McCombie (2013) }\end{array}$ & Thailand & VECM & $\begin{array}{l}\text { Multi- } \\
\text { Sectoral } \\
\text { Version }\end{array}$ & $1962-2006$ & $\begin{array}{c}\text { Producer and Unit Value } \\
\text { Price Indexes in US } \\
\text { dollars }\end{array}$ & - \\
\hline $\begin{array}{l}\text { Gouvea and Lima } \\
(2013)\end{array}$ & 92 Countries & $\mathrm{FE}$ & $\begin{array}{l}\text { Multi- } \\
\text { Sectoral } \\
\text { Version }\end{array}$ & $1962-2006$ & 1/PPP & Reg.* \\
\hline $\begin{array}{l}\text { Romero and } \\
\text { McCombie } \\
(2016 b)\end{array}$ & $\begin{array}{l}14 \mathrm{EU} \\
\text { Countries }\end{array}$ & $\begin{array}{l}\text { VECM, } \\
\text { SYS-GMM } \\
\text { Product- } \\
\text { panel }\end{array}$ & $\begin{array}{l}\text { Multi- } \\
\text { Sectoral } \\
\text { Version }\end{array}$ & $1984-2007$ & $\begin{array}{c}\text { Relative product-level } \\
\text { quality-adjusted price } \\
\text { indexes }\end{array}$ & Reg.* \\
\hline
\end{tabular}


Hence, the discussion presented in this section suggests that it is crucial to carry out further research on the determinants of the magnitude of income elasticities. In spite of the contributions discussed above, more work is necessary to identify more precisely the determinants of differences in income elasticities of different products.

\section{Cumulative causation}

\subsection{The Kaldor-Dixon-Thirlwall model}

In contrast with neoclassical growth theory, which puts more emphasis on the role of mechanisms that generate convergence, Kaldor (1970) emphasised the importance of cumulative mechanisms that slow down convergence or make economies diverge.

The Kaldor-Dixon-Thirlwall model is the canonical model of growth from a Kaldorian perspective. As the name indicates, the model was developed by Dixon and Thirlwall (1975) in an attempt to formally describe Kaldor's $(1966,1970)$ ideas about increasing returns, exportled growth, and cumulative causation. Although this model preceded the balance-of-payments constrained growth model, it seems more appropriate to present it last, given that the KaldorDixon-Thirlwall model and its expansions seek to encompass the main ideas of the Kaldorian approach. In the model, productivity growth leads to a reduction in prices (ceteris paribus), which leads to an increase in export growth, which generates output growth through Hick's super-multiplier. Finally, output growth generates productivity growth through KaldorVerdoorn's Law, restarting the process.

The model is composed of four equations: Kaldor-Verdoorn's Law; the standard export demand function; Hicks' (1950) super-multiplier; ${ }^{6}$ and a dynamic price function, in which changes in prices depend on changes in wages, productivity, and mark-up. ${ }^{7}$ Formally, the model is described as follows:

$$
\begin{aligned}
& \hat{Q}=\rho+\lambda \hat{Y} \\
& \hat{X}=\eta\left(\hat{P}-\hat{P}_{f}-\hat{E}\right)+\varepsilon \hat{Z} \\
& \hat{Y}=\gamma \hat{X} \\
& \hat{P}=\hat{W}-\hat{Q}-\hat{V}
\end{aligned}
$$

where $\gamma$ is elasticity of output growth in relation to export growth, $\mathrm{W}$ is the wage rate, and $\mathrm{V}$ is the rate of mark-up ( $1+\%)$ on unit labour costs.

Thus, combining equations (19), (20), (9) and (1) gives the model's equilibrium growth rate:

$$
\hat{Y}^{*}=\gamma\left[\frac{\left.\eta\left[(\hat{W}-\rho+\hat{V})-\hat{P}_{f}\right)\right]+\varepsilon \hat{Z}}{1+\gamma \eta \lambda}\right]
$$

Three aspects of the model are worth noting. First, since $\eta<0$, the output growth rate varies positively with increases in $\hat{Q}, \hat{P}_{f}, \hat{E}, \varepsilon, \hat{Z}$ and $\lambda$; and negatively with increases in w

\footnotetext{
${ }^{6}$ Thirlwall (1983) identifies seven laws in Kaldor's thinking. According to him, the central role of exports on income growth is Kaldor's sixth law.

${ }^{7}$ In levels, the mark-up pricing rule is given by $P=(W / Q) V$.
} 
and v. Second, it is the impact of the Verdoorn coefficient on productivity that makes the model cumulative. An initial shock, e.g. an exogenous increase in the growth rate of world income $(\hat{Z})$, leads to higher export and income growth, which impacts the economy's productivity through the Verdoorn coefficient, generating a fall in export prices, leading to a new increase in exports. The magnitude of the equilibrium output growth rate, therefore, depends directly on the magnitude of the Verdoorn coefficient and the other parameters of the model. And third, a growth advantage resulting from an autonomous shock will only be sustained if the initial shock affects the parameters of the model. Otherwise, the model will converge back to the initial equilibrium (Dixon and Thirlwall, 1975, p. 206-7). In sum, differences in output growth rates between countries or regions in this model depend on the levels of the Verdoorn coefficient and the other parameters of the model.

Hence, to assess the adjustment process in this model, Dixon and Thirlwall (1975) take into account a lagged exports function:

$$
\hat{X}_{t}=\eta\left(\hat{P}_{t-1}-\hat{P}_{f t-1}-\hat{E}_{t-1}\right)+\varepsilon \hat{Z}_{t-1}
$$

Then, combining equation (22) with equations (19), (20) and (1), and rearranging its terms gives the lagged general solution:

$$
\hat{Y}_{t}=A(-\gamma \eta \lambda)^{t}+\gamma\left[\frac{\left.\eta\left[\left(\hat{W}_{t-1}-\rho+\hat{V}_{t-1}\right)-\hat{P}_{f t-1}\right)\right]+\varepsilon \hat{Z}_{t-1}}{1+\gamma \eta \lambda}\right]
$$

where $A$ is the initial condition.

Equation (23) indicates that the model's stability depends on the magnitude of the term $\gamma \eta \lambda$. Keeping in mind that $\eta<0$, so that $(-\gamma \eta \lambda)>0$, for divergence to take place it is necessary that $(-\gamma \eta \lambda)>1$. As Dixon and Thirlwall $(1975$, p. 208) argue, taking realistic values of the parameters, divergence is unlikely. In contrast, if $(-\gamma \eta \lambda)<1$ differences in growth rates between countries or regions are constant over time. Hence, for divergence to occur the parameters must change through time, so that the equilibrium growth rates keep changing. As Roberts (2002) argues, however, it is important to note that there are actually two cumulative causation mechanisms in the model. On the one hand, differences in the Verdoorn coefficient work to sustain disparities in productivity growth rates. On the other hand, when a region is out of its equilibrium rate of productivity growth, the impact of the Verdoorn coefficient on price competitiveness accelerates export growth, pushing the productivity growth rate towards its equilibrium.

As Thirlwall and Dixon (1979) have demonstrated, a balance-of-payments constraint can be easily incorporated into the Kaldor-Dixon-Thirlwall model by replacing equation (19) with the balance-of-payments equilibrium condition given by equation (11), and introducing into the model the standard import demand function given by equation (10). Thus, as Blecker (2013) argued, introducing a balance-of-payments constraint into the Kaldor-Dixon-Thirlwall model does not necessarily change the implications of the model. ${ }^{8}$ As long as relative prices are not constant and the Marshal-Lerner condition does hold, cumulative causation can affect the equilibrium growth rate represented in equation (12), and the main ideas in the KaldorDixon-Thirlwall model are sustained.

\footnotetext{
${ }^{8}$ See Blecker (2013) for a version of this model that includes capital flows and debt accumulation.
} 
4.2. The Kaldor-Dixon-Thirlwall model with balance-of-payments constraint and cumulative causation via non-price competition

The Kaldor-Dixon-Thirlwall model described in the previous sections has been critised due the fact that cumulative causation in model works through price competitiveness. A vast literature provides evidence that, in the long run, price elasticities of demand do not have a significant effect on export growth, either because relative prices are constant in the long-term, or because the Marshal-Lerner condition is not satisfied (Blecker, 2013). In these cases, the model's cumulative causation ceases to exist, given that productivity gains generated by increasing returns feed back on growth only via price competitiveness. Moreover, the more prominent role of price competitiveness in relation to non-price competitiveness in the KaldorDixon-Thirlwall model is conflicting with the emphasis put into this type of competition in the balance-of-payments constrained growth models (see M cCombie and Thirlwall, 1994).

Setterfield (2011) proposed a simple solution to this critique, changing the channel through which cumulative causation operates in model. ${ }^{9}$ According to Setterfield (2011, p. 415), "the basic hypothesis here is that the higher is the level of productivity, the higher is the quality of goods produced in a particular region, and so the larger will be the increase in demand for the region's output associated with any given increase in income (ceteris paribus)" ${ }^{10}$ If productivity impacts on non-price competitiveness, then cumulative growth occurs in spite of the insignificance of the long-term effects of price competitiveness on export growth. ${ }^{11}$ This non-price competitiveness version of the Kaldor-Dixon-Thirlwall model is obtained substituting the effect of productivity on prices with two equation that associate levels of income elasticities of exports and imports with levels of productivity, while assuming that Kaldor-Verdoorn's Law is valid for both the domestic and the foreign economies. In this model, the equilibrium growth rate is given by Thirlwall's Law (equation (13)), which assumes either that relative prices are constant or that the Marshal-Lerner condition is not fulfilled.

$$
\begin{aligned}
& \hat{Q}=\rho+\lambda \hat{Y} \\
& \hat{Y}=\frac{\varepsilon}{\pi} \hat{Z} \\
& \varepsilon=\delta Q \\
& \pi=\phi Q_{f} \\
& \hat{Q}_{f}=\rho+\lambda \hat{Z}
\end{aligned}
$$

where $Q_{f}$ denotes productivity in the foreign economy.

Equations (24) and (25) imply that:

\footnotetext{
${ }^{9}$ A similar solution was proposed by Roberts (2002).

${ }^{10}$ In a similar fashion, Oreiro, Missio e Jayme Jr. (2015) proposed that the magnitude of income elasticities of demand are partially endogenous to the real exchange rate. However, although there is considerable evidence that under-valued exchange rates have a positive impact on growth rates (e.g. Rodrik, 2008; Rapetti, Skott and Razmi, 2013; M issio et al., 2015), no empirical works to date has yet found evidence that income elasticities of demand for export and imports are endogenous to the real exchange rate.

${ }^{11}$ In a slightly different approach, Raposo and Resende (2011) argue that trade balance depends on the level of development of National Innovation Systems, so that the external constraint on growth is less binding in countries with more developed systems. Nonetheless, it is possible to argue that countries with mature National Innovation Systems tend to have higher levels of productivity. Hence, this would be a second-order explanation following Setterfield's (2011) approach.
} 
$\dot{\kappa}=\kappa\left(\hat{Q}-\hat{Q}_{f}\right)$

where $\kappa=\varepsilon / \pi$.

Then, it follows from (1), (26) and (13) that:

$\dot{\kappa}=\kappa[\lambda(\kappa-1) \hat{Z}]$

Several implications follow from this model (Setterfield, 2011, p. 416-17). First, if $\kappa=1$, then the domestic and foreign growth rates ( $\hat{Y}$ and $\hat{Z}$, respectively) will be equal, which means there will be balanced growth. Furthermore, this implies that $\dot{\kappa}=0$, so that balanced growth is self-perpetuating. Second, if $\kappa>1$, then the local economy will grow faster than the rest of the world. In this case, $\dot{\kappa}>0$, and domestic growth will be self-reinforcing, which means cumulative growth will lead to ongoing divergence between the two growth rates. Third, if $\kappa<1$, then $\dot{\kappa}<0$, and there will be a self-reinforcing vicious cycle of reduction in growth rates. Hence, the prediction of unbounded increases or reductions in growth rates represents an important limitation of this model.

Taking into account Setterfield's (2011) approach, Romero and McCombie (2016c) sought to combine the Kaldorian and Schumpeterian approaches on trade and test the impact of domestic and frontier productivity growth (used as a proxy for quality improvements) on export and import growth. Using disaggregated data for a group of OECD countries to test these expanded export and import functions, the authors find evidence that introducing domestic and frontier productivity growth impacts the magnitude of the estimated income elasticities of demand. These results indicate that excluding these variables from the regressions creates an omitted variable bias in the income elasticities, which suggests their endogeneity in relation to productivity, as Setterfield (2011) argues.

\subsection{León-Ledesma's expanded Kaldor-Dixon-Thirlwall growth model}

A number of works have sought to combine Kaldorian and Schumpeterian insights into models of cumulative growth, addressing one or more of the critiques directed to the Kaldor-DixonThirlwall model. Still, none of these seminal works has managed to construct a model that satisfactorily encompasses the contributions of both traditions. Amable (1993), for instance, put together a model that takes into account the importance of both research intensity and technology transfer for productivity growth. Nonetheless, the model does not specify how productivity growth impacts on output growth nor considers the role of exports in long-term growth. Furthermore, the cumulative mechanism of the model works via investment and not via output growth, as in Kaldor-Verdoorn's Law. This reduces the explanatory power of the model, given that an extensive literature stresses the importance of output growth instead of capital accumulation for productivity growth. Targetti and Foti (1997), in turn, elaborated a model that stresses the importance of technology transfer for productivity growth, but that does not account for the role of research intensity nor explicitly consider the effect of nonprice competitiveness on exports. In addition, the model does not account for the balance-ofpayments constraint. Hence, these two influential models combine Kaldorian and Schumpeterian insights in an incomplete manner.

León-Ledesma's (2002) model represents the most complete formalization of Kaldorian and Schumpeterian insights. The author expanded the Kaldor-Dixon-Thirlwall model to incorporate the key Schumpeterian insights on growth, introducing the technology gap, research intensity and technological competitiveness into the Kaldorian model. This model is composed of the five following equations: 


$$
\begin{aligned}
& \hat{Y}=\gamma \hat{X} \\
& \hat{P}=\hat{W}-\hat{Q} \\
& \hat{Q}=\rho+\lambda \hat{Y}+\alpha T+\sigma G+\beta(I / Y) \\
& \hat{X}=\eta\left(\hat{P}-\hat{P}_{f}\right)+\varepsilon \hat{Z}+\chi T+\delta(I / Y) \\
& T=\mu \hat{Y}+\varpi \hat{D}+\omega S-\varsigma G
\end{aligned}
$$

where $T=R / Y$ is research intensity, with $R$ denoting $R \& D$ expenditure, $I$ is investment, $S$ is the average level of education, $D$ (for disembodied technical progress) is cumulative output, and $G=\left[1-\left(Q / Q_{f}\right)\right]$ is the technology gap.

The five equations of the model incorporate the central aspects of the Kaldorian and the Schumpeterian traditions. Equations (19) and (20) are the same as the original model, while equation (29) is an expanded version of Kaldor-Verdoorn's Law, which introduces the effects of technological absorption (via the technology gap), capital accumulation, and research intensity on productivity growth. The Schumpeterian literature emphasises the importance of technological transfer for productivity growth, arguing that due to technological absorption, the higher the technology gap is, the higher the potential for rapid productivity growth is (e.g. Griffith et al., 2004). Indeed, it is now common practice to take into account the technology gap when estimating Kaldor-Verdoorn's Law. As McCombie (1983) has shown, not taking into account differences in technology between countries or regions can bias the estimates. In addition, introducing the technology gap generates a connection between the level and the growth rate of productivity, making conditional convergence explicitly accounted for in the model. ${ }^{12}$ Furthermore, the Schumpeterian literature stresses the importance of research intensity for productivity growth, underlining that a firm's effort to innovate influences the pace of technological progress (e.g. Ha and Howitt, 2007; Madsen, 2008). Thus, the expanded Kaldor-Verdoorn's Law takes into account the effect of the determinants of productivity growth from a Schumpeterian perspective. Similarly, equation (30) is an expanded version of the standard export function used in the Kaldor-Dixon-Thirlwall model, incorporating the effects of productive capacity (via capital accumulation) and technological competitiveness (via research intensity) on export growth. Thus, once again factors that are considered relevant determinants of trade in the Schumpeterian tradition (e.g. Fagerberg, 1988; Amable and Verspagen, 1995) are introduced into the Kaldorian approach to trade. Finally, equation (31) suggests that the level of research intensity depends on demand growth $(\hat{Y})$, on learning-by-doing $(\hat{D})$, on the average level of education $(S)$ and on the proximity to the technological frontier, i.e. the technology gap. The gap has a negative sign, therefore, to indicate that the higher it is, the lower are the resources available to research.

According to the model, convergence or divergence depends on the magnitudes of the gap and of the models' parameters. It is interesting to note that the gap has an ambiguous effect. On the one side, the impact of technological transfer (which depends on the technology gap) on productivity is the main force leading to convergence. On the other side, the negative impact of the technology gap on innovation induces divergence. León-Ledesma's (2002) extended Kaldor-Dixon-Thirlwall model, therefore, not only explains convergence and divergence in a Kaldorian framework, but it also takes into account the cumulative dynamics

\footnotetext{
${ }^{12}$ Although Roberts (2007) has shown that the Kaldor-Dixon-Thirlwall model is compatible with condition convergence, this convergence occurs due to the transitional dynamics of the model. Introducing the technology gap into the model, however, provides a better explanation for conditional convergence.
} 
that work via non-price competitiveness, incorporating the key variables used in Schumpeterian growth models.

León-Ledesma (2002) tested the model using pooled data between 1965-94 for 17 OECD countries and found that all the variables in the model are significant in each specific equation, apart from output growth in equation (31), and capital accumulation and research intensity in equation (29). Furthermore, it is crucial to note that learning-by-doing $(\hat{D})$ is only significant at the $15 \%$ level in equation (31).

In spite of the interesting dynamics depicted in León-Ledesma's (2002) model, it still presents some shortcomings. First, the model disregards the importance of the balance-ofpayments constraint for long-term growth, as occurs with Amable's (1993) and Targetti and Foti's (1997) models, inter alia. Second, the model does not take sectoral differences into account, disregarding the importance of differences in the parameters between sectors. Indeed, most models that have attempted to combine Kaldorian and Schumpeterian insights did not consider sectoral differences. ${ }^{13}$ Third, if the balance-of-payments constraint is introduced into the model and relative prices are assumed to be constant in the long run, then the model's cumulative causation ceases to exist, as happens with the Kaldor-Dixon-Thirlwall model. In this case, productivity growth becomes irrelevant, while research intensity keeps its role in long-term growth due to its impact on exports. Thus, supply-side factors become more prominent, given that demand factors are not significant determinants of research intensity. Fourth, in León-Ledesma's (2002) tests, research intensity is not a significant determinant of productivity growth, which goes against one of the core ideas of the Schumpeterian literature. Hence, this discussion illustrates the issues involved in combining Kaldorian and Schumpeterian insights on growth.

\subsection{Empirical evidence}

There is little empirical research focused on testing the canonical Kaldor-Dixon-Thirlwall model. There is considerable evidence for the relationship between exports and output growth, while it is a consensus that productivity growth induces price reductions. Consequently, the controversies that surround the Kaldor-Dixon-Thirlwall model regard the validity of Kaldor-Verdoorn's Law and of Thirlwall's Law. Thus, most of the empirical works in the Kaldorian literature have focused on testing these two laws, as discussed in the previous sections. Yet, a noteworthy exception is Atesoglu's (1994) study, which tested the KaldorDixon-Thirlwall model to the US economy between 1970 and 1990. The author not only found that the relationships of the model are significant and with the expected signs, but he also found that the model predicts extremely well the growth path of the US economy in the period under investigation.

Still, the Kaldor-Dixon-Thirlwall model has received three important critiques. First, the original model places little emphasis on the importance of non-price competitiveness, focusing on price competitiveness instead. This is an important critique, given that this makes the model inconsistent with empirical evidence on the neutrality of price competition in the longterm, making the model lose its cumulative mechanism. Moreover, attempts to solve this limitation, as Setterfield's (2011) model, have not been empirically tested to date. Second, the central parameters of the model are not explained. The price elasticity of exports, the Verdoorn coefficient, and the elasticity of output with respect to exports are the parameters that determine the magnitude of the equilibrium growth rate. Nonetheless, the model does

\footnotetext{
${ }^{13}$ Cimoli and Porcile's (2014) model is an exception. However, the model is inspired in a structuralist framework that is very different from Schumpeterian and Kaldorian models.
} 
not provide any explanation for what determines the magnitude of these parameters between countries (or regions) and through time. Furthermore, not much research has focused on explaining the determinants of these parameters, as the reviews presented in the previous sections have demonstrated. Third, the model does not take into account differences between sectors. ${ }^{14}$ Recent evidence has also shown that income elasticities of demand for exports are also different between sectors, reaffirming the importance of taking sectoral differences into account.

Most of the works that explore the dynamics of the Kaldor-Dixon-Thirlwall model have tried to elaborate and test expanded versions of the model (e.g. Amable, 1993; Setterfield, 1997; Targetti and Foti, 1997; León-Ledesma, 2002). Interestingly, most of the efforts have been focused on incorporating elements from Schumpeterian theory into the Kaldor-DixonThirlwall model. In the last decades the Schumpeterian approach to technological transfer and technical progress has gained a prominent place in growth theory (see Aghion and Howitt, 1992; Fagerberg, 2005). In Kaldorian theory, it is now common to introduce measures of technology gap to capture technological transfer when estimating Kaldor-Verdoorn's Law (e.g. Angeriz et al., 2008; 2009), while technological classifications that emphasise the importance of research have been used to assess the importance of the technological content of goods for export performance and long-term growth according to Thirlwall's Law (e.g. Gouvea and Lima, 2010; Romero et al., 2011). Still, there is more to explore in combining Kaldorian and Schumpeterian insights.

\section{Concluding remarks}

This paper sought to demonstrate that Kaldor's ideas form a sound basis for understanding long-term growth. The literature review presented in this paper identified three important gaps in the Kaldorian literature, each one constituting an important area for future research. Firstly, both in Kaldor-Verdoorn's Law and in Thirlwall's Law, the key parameters of the model have not been fully understood. In the former, it is still not clear what determines differences in the degree of returns to scale across countries, sectors and through time. In the latter, it is also not clear what are the specific determinants of the magnitudes of income elasticities of demand for exports and imports. In both cases, exploring the effects of additional variables could help clarify what determines the magnitudes of these parameters, as have been sought by the works that combine Kaldorian and Schumpeterian insights. Secondly, the fact that cumulative causation works through price competitiveness in the Kaldor-Dixon-Thirlwall model represents an important limitation of the model. A vast literature provides evidence that, in the long run, changes in relative price do not have a significant effect on export growth, either because relative prices are constant in the long-term, or because the Marshal-Lerner condition is not satisfied. In these cases, the model loses its mechanism of cumulative causation, given that productivity gains generated by increasing returns feed back on growth only through price competition. Thirdly, sectoral differences have not been fully explored in Kaldorian theory. Although several works have investigated the validity of Kaldor-Verdoorn's Law for different sectors, only recently has the relationship between increasing returns and the technological content of goods been tested. Similarly, only recently has Thirlwall's Law been disaggregated to test the differences in the income elasticities across different sectors to assess whether the economic structure of each country influences its aggregate income elasticities. Hence, further

\footnotetext{
${ }^{14}$ Araújo (2013) has sought to address this limitation developing a multi-sectoral version of the KaldorDixon-Thirlwall inspired in the Pasinettian Structural Economic Dynamics framework. Although the model incorporates the classic insights of the Kaldor-Dixon-Thirlwall model, its Pasinettian form makes the model considerably different.
} 
work is still necessary to properly assess the relationship between structural change and economic growth from a Kaldorian perspective.

\section{References}

Alexiadis, S.; Tsagdis, D. (2010). "Is cumulative growth in manufacturing productivity slowing down in the EU12 regions?", Cambridge Journal of Economics, 34, p. 1001-1017.

Alonso, J. A.; Garcimartín, C. (1998). "A New Approach to Balance-of-Payments Constraint: Some Empirical Evidence", Journal of Post Keynesian Economics, 21(2), p. 259-82.

Aghion, P.; Howitt, P. (1992). "A M odel of Growth Through Creative Destruction, Econometrica, 60(2), p. 323-351.

Amable, B. (1993). "Catch-up and Convergence: a model of cumulative causation", International Review of Applied Economics, 7(1), p. 1-25.

Amable, B.; Verspagen, B. (1995). "The Role of Technology in Market Share Dynamics", Applied Economics, 27(2), p. 127-204.

Andersen, P. S. (1993). "The 45-rule revisited", Applied Economics, 25, p. 1279-1284.

Angeriz, A.; McCombie, J. S.; Roberts, M. (2008). "New Estimates of Returns to Scale and Spatial Spillovers for EU Regional Manufacturing, 1986-2002", International Regional Science Review, 31(1), p. 62-87.

Angeriz, A.; McCombie, J. S.; Roberts, M. (2009). "Increasing Returns and the Growth of Industries in the EU Regions: Paradoxes and Conundrums", Spatial Economic Analysis, $4(2)$, p. 127-48.

Araújo, R. (2013). "Cumulative causation in a structural economic dynamic approach to economic growth and uneven development", Structural Change and Economic Dynamics, 24, p. 130-140.

Araújo, R.; Lima, G. T. (2007). "A structural economic dynamics approach to balance-ofpayments-constrained growth", Cambridge Journal of Economics, 31(5), p. 755-74.

Ansari, M.; Hashemzadeh, N.; Xi, Y. (2000). "The Chronicle of Economic Growth in Southeast Asian Countries: Does Thirlwall's Law Provide an Adequate Explanation?", Journal of Post Keynesian Economics, 22(4), p. 573-588.

Atesoglu, H. S. (1993a). "Balance-of-Payments-Constrained Grwoth: Evidence from the United States", J ournal of Post Keynesian Economics, 15(4), p. 507-14.

Atesoglu, H. S. (1993b). "Exports, Capital Flows, Relative Prices and Economic Growth in Canada", Journal of Post Keynesian Economics, 16(2), p. 289-97.

Atesoglu, H. S. (1994). "An application of a Kaldorian export-led model of growth to the United States", Applied Economics, 26, p. 479-483.

Bairam, E. (1988). "Balance of payments, the Harrod foreign trade multiplier and economic growth: the European and North American experience, 1970-85", Applied Economics, 20, p. $1635-42$.

Bairam, E.; Dempster, G. J. (1991). "The Harrod foreign trade multiplier and economic growth in Asian countries", Applied Economics, 23, p. 1719-24.

Barbosa-Filho, N. H. (2001). "The balance-of-payments constraint: from balanced trade to sustainable debt", BNL Quarterly Review, 54, p. 381-400. 
Bernat, G. A. (1996). "Does Manufacturing Matter? A Spatial Econometricl View of Kaldor's Laws", Journal of Regional Science, 36, p. 463-77.

Blecker, R. (2013). "Long-run growth in open economies: export-led cumulative causation or balance-of-payments constraint?", in Harcourt, G. C.; Kriesler, P. (eds) Oxford Handbook of Post Keynesian Economics (4 vols.). Oxford: Oxford University Press.

Britto, G.; McCombie, J. S. L. (2009). "Thirlwall's law and the long-term equilibrium growth rate: an application to Brazil", Journal of Post Keynesian Economics, 32(1), p. 115-136.

Britto, G.; McCombie, J. S. L. (2015). "Increasing returns to scale and regions: a multilevel model for Brazil", Brazilian Keynesian Review, 1(2), p. 118-34.

Cimoli, M.; Porcile, G. (2014). "Technology, structural change and balance-of-paymentsconstrained growth: a structuralist toolbox", Cambridge Journal of Economic, 38, p. 215-237.

Dixon, R.; Thirwall, A. P. (1975). "A M odel of Regional Growth-rate Differences on Kaldorian Lines", Oxford Economic Papers, 27(2), p. 201-214.

Fagerberg, J. (1988). "International Competitiveness", Economic Journal, 98(391), p. 355-374.

Fagerberg, J. (2005). "Innovation: a guide to the literature", in Fagerebrg, J.; Mowery, D.; Nelson, R. (Eds.) The Oxford Handbook of Innovation. Oxford: Oxford University Press.

Felipe, J.; Hasan, R.; McCombie, J. S. L. (2008). "Correcting for biases when estimating production functions: an illusion of the laws of algebra?", Cambridge Journal of Economics, 32, p. 441-459.

Fingleton, B.; M cCombie, J. S. L. (1998). "Increasing Returns and Economic Growth: Some New Evidence from Manufacturing from the European Union Regions", Oxford Economic Papers, 50, p. 89-105.

Garcimartín, C.; Rivas, L. A.; Martínez, P. G. (2010). "On the role of relative prices and capital flows in balance-of-payments constrained growth: the experiences of Portugal and Spain in the euro area", Journal of Post Keynesian Economics, 33(2), p. 281-305.

Gouvea, R. R.; Lima, G. T. (2010). "Structural change, balance-of-payments constraint, and economic growth: evidence from the multisectoral Thirlwall's Law", Journal of Post Keynesian Economics, 33(1), p. 169-204.

Gouvea, R. R.; Lima, G. T. (2013). "Balance-of-payments-constrained growth in a multisectoral framework: a panel data investigation", Journal of Economic Studies, 40(2), p. 240-254.

Griffith, R.; Redding, S.; Van Reenen, J. (2004). "Mapping the two faces of R\&D: productivity growth in a panel of OECD Industries", Review of Economics and Statistics, 86(4), p. 883-895.

Grossman, G. M.; Helpman, E. (1991). Innovation and Growth in the Global Economy. Cambridge M A: MIT Press.

Ha, J.; Howitt, P. (2007). "Accounting for Trends in Productivity and R\&D: A Schumpeterian Critique of Semi-Endogenous Growth Theory", Journal of M oney, Credit and Banking, 39(4), p. 733-774.

Hansen, J. D.; Zhang, J. (1996). "A Kaldorian Approach to Regional Economic Growth in China", Applied Economics, 28, p. 679-85. 
Harris, R. I. D.; Liu, A. (1999). “Verdoorn's Law and Increasing Returns to Scale: Country Estimates Based on the Cointegration Approach", Applied Economics Letters, 6, p. 2933.

Harrod, R. F. (1933). International Economics. Cambridge: Cambridge University Press.

Heike, H. (1997). "Balance-of-Payments-Constrained Growth: A Reconsideration of the Evidence for the US Economy", J ournal of Post Keynesian Economics, 19(3), p. 313-325.

Hicks, J. R. (1950). A Contribution to the Theory of the Trade Cycle. Oxford: Clarendon Press.

Houthakker, H. S.; Magee, S. P. (1969). "Income and price elasticities in world trade", Review of Economic and Statistics, 51(2), p. 111-125.

Kaldor, N. (1957). "A M odel of Economic Growth", Economic Journal, 67, p. 591-624.

Kaldor, N. (1966). Causes of the Slow Rate of Economic Growth of the United Kingdom: an Inaugural Lecture. Cambridge: Cambridge University Press.

Kaldor, N. (1970). "The Case for Regional Policies", Scottish Journal of Political Economy, 17, p. $337-48$.

Keynes, J. M. (1936). The General Theory of Employment, Interest and Money. London: Macmillan.

Kleinknecht, A.; Verspagen, B. (1990). "Demand and Innovation: Schmookler re-examined", Research Policy, 19, p. 387-394.

León-Ledesma, M. A. (1999). "Verdoorn's Law and increasing returns: an empirical analysis of the Spanish regions", Applied Economics Letters, 6, p. 373-6.

León-Ledesma, M. A. (2000). “Economic Growth and Verdoorn's Law in the Spanish Regions, 1962-91", International Review of Applied Economics, 14(1), p. 55-69.

León-Ledesma, M. A. (2002). "Accumulation, innovation and catching-up: an extender cumulative growth model", Cambridge Journal of Economics, 26, p. 201-216.

M cCombie, J. S. L. (1982). “Economic Growth, Kaldor's Laws and the Static-Dynamic Verdoorn Law Paradox", Applied Economics, 14, p. 279-94.

McCombie, J. S. L. (1983). "Kaldor's laws in retrospect", Journal of Post-Keynesian Economics, 5(3), p. 414-429.

McCombie, J. S. L. (1985). "Economic growth, the Harrod foreign trade multiplier and the Hicks' super-multiplier", Applied Economics, 17, p. 55-72.

McCombie, J. S. L. (1997). "On the Empirics of Balance-of-Payments-Constrained Growth", Journal of Post Keynesian Economics, 19(3), p. 345-375.

McCombie, J. S. L. (2002). "Increasing Returns and the Verdoorn Law from a Kaldorian Perspective", in M cCombie, J. S. L.; Pugno, M.; Soro, B. (Eds.) Productivity Growth and Economic Performance: Essays on Verdoorn's Law. New York: Palgrave M acM illan.

McCombie, J. S. L. (2011). "Criticisms and defences of the balance-of-payments constrained growth model: some old, some new", PSL Quarterly Review, 64(259), p. 353-392.

McCombie, J. S. L.; De Ridder, J. R. (1983). "Increasing returns, productivity, and output growth: the case of the United States", Journal of Post-Keynesian Economics, 5(3), p. 373-387.

McCombie, J. S. L.; De Ridder, J. R. (1984). "The Verdoorn Law Controversy: Some New Empirical Evidence Using U.S. State Data”, Oxford Economic Papers, 36(2), p. 268-284. 
McCombie, J. S. L.; Roberts, M. (2007). "Returns to Scale and Regional Growth: The StaticDynamic Verdoorn Law Paradox Revisited", Journal of Regional Science, 47(2), p. 179208.

McCombie, J. S. L.; Thirlwall, A. (1994). Economic Growth and the Balance-of-Payments Constraint. London: M acmillan Press Ltd..

McCombie, J. S. L.; Thirlwall, A. (1997). "Economic Growth and the balance-of-payments constraint revisited", in Arestis, P.; Palma, G.; Sawyer, M. (Eds.), Markets, unemployment and economic policy: essays in honour of Geoff Harcourt. London: Routhledge.

McCombie, J. S. L.; Spreafico, M. (2016). "Kaldor's 'Technical Progress Function' and the Verdoorn Law Revisited", Cambridge Journal of Economics, 40(4), p. 1117-1136.

Missio, F. J.; Jayme Jr., F. G.; Britto, G.; Oreiro, J. L. (2015). "Real Exchange Rate and Economic Growth: New Empirical Evidence”, Metroeconomica, 66, p. 686-714.

Moreno-Brid, J. C. (2003). "Capital flows, interest payments and the balance-of-payments constrained growth model: a theoretical and empirical analysis", Metroeconomica, 54(2), p.346-65.

M yrdal, G. (1957). Economic Theory and Underdeveloped Regions. London: Duckworth.

Oliveira, F. H. P.; Jayme Jr., F. G.; Lemos, M. B. (2006). "Increasing returns to scale and international diffusion of technology: An empirical study for Brazil (1976-2000)", World Development, 34(1), p. 75-88.

Oreiro, J. L.; Missio, F. J.; Jayme Jr., F. G. (2015). "Capital Accumulation, Structural Change and Real Exchange Rate in a Keynesian-Structuralist Growth Model", Panoeconomicus, 62, p. 237-256.

Perraton, J. (2003). "Balance of Payments Constrained Growth and Developing Countries: an examination of Thirlwall's hypothesis", International Review of Applied Economics, 17(1), p. 1-22.

Pieper, U. (2003). "Sectoral regularities of productivity growth in developing countries - a Kaldorian interpretation", Cambridge Journal of Economics, 27, p. 831-850.

Rapetti, M.; Skott, P.; Razmi, A. (2012). "The real exchange rate and economic growth: are developing countries different?", 29(4), p. 267-79.

Raposo, D. A.; Resende, M. F. C. (2011). "National Innovation System and External Constraint on Growth: theoretical approach and some empirical evidence", Research Network Macroeconomics and Macroeconomic Policies (FM M ) 15th Conference, Berlin.

Roberts, M. (2002). "Cumulative Causation and Unemployment", in McCombie, J. S.; Pugno, M.; Soro, B. (Eds.), Productivity Growth and Economic Performance: Essays on Verdoorn's Law. New York: Palgrave M acM illan.

Rodrik, D. (2008). "The real exchange rate and economic growth", Brookings Papers on Economic Activity, 39(2), p. 365-439.

Romer, P. (1990). "Endogenous Technological Change", Journal of Political Economy, 98(5), p. S71-S102.

Romero, J. P.; Britto, G. (2016). “Increasing Returns To Scale, Technological Catch-up And Research Intensity: Endogenising the Verdoorn Coefficient", Cambridge Journal of Economics, forthcoming. 
Romero, J. P.; McCombie, J. S. L. (2016a). "Differences in Increasing Returns Between Technological Sectors: A Panel Data Investigation Using the EU KLEMS Database", Journal of Economic Studies, forthcoming.

Romero, J. P.; M cCombie, J. S. L. (2016b). "The Multi-Sectoral Thirlwall's Law: evidence from 14 developed European countries using product-level data", International Review of Applied Economics, 30(3), p. 301-25.

Romero, J. P.; McCombie, J. S. L. (2016c). "Thirlwall's Law and the Specification of Export and Import Demand Functions: An Investigation of the Impact of Relative Productivity Growth on Trade Performance", Cambridge Centre for Economic and Public Policy Working Papers Series, CCEPP WP 02-2016.

Romero. J. P.; Silveira, F.; Jayme Jr., F. G. (2011). "Brazil: structural change and balance-ofpayments-constrained growth", CEPAL Review, 105, p. 185-208.

Rowthorn, R. E. (1975). “What Remains of Kaldor's Law?”, Economic Journal, 85(337), p. 10-19.

Setterfield, M. (1997). "'History versus equilibrium' and theory of economic growth", Cambridge Journal of Economics, 21, p. 365-378.

Setterfield, M. (2011). "The remarkable durability of Thirlwall's Law", PSL Quarterly Review, 64(259), p. 393-427.

Smith, A. (1776 [1973]). An Inquiry into the Nature and Causes of the Wealth of Nations. Harmondsworth: Penguin Book.

Schmookler, J. (1966). Invention and Economic Growth. Cambridge MA: Harvard University Press.

Targetti, F.; Foti, A. (1997). "Growth and productivity: a model of cumulative growth and catching up", Cambridge Journal of Economics, 21, p. 27-43.

Tharnpanich, N.; McCombie, J. S. L. (2013). "Balance-of-payments constrained growth, structural change, and the Thai economy", Journal of Post Keynesian Economics, 35(4), p. 569-97.

Thirlwall, A. (1979). "The Balance of Payments Constraint as an Explanation of International Growth Rate Differences", BNL Quarterly Review, 128(791), p. 45-53.

Thirlwall, A. (1983). "A Plain Man's Guide to Kaldor's Growth Laws", Journal of Post Keynesian Economics, 5(3), p. 345-358.

Thirlwall, A.; Dixon, R. J. (1979). "A Model of Export-Led Growth with Balance of Payments Constraint", in Bowers, J. K. (ed) Inflation, Development and Integration: Essays in Honour of A. J. Brown, Leeds: Leeds University Press.

Thirlwall, A.; Hussain, M. N. (1982). "The Balance of Payments Constraint, Capital Flows and Growth Rate Differences between Developing Countries", Oxford Economic Papers, 34(3), p. 498-510.

Verdoorn, P. J. (1949). "Fattori che regolano lo sviluppo della produttività del lavoro", L'Industria, 1, p. 3-10. 